\title{
Can human micronutrient status be improved by supplementing domestic animals?
}

\author{
Susanne Bügel \\ Department of Human Nutrition, The Royal Veterinary and Agricultural University, \\ Rolighedsvej 30, 1958 Frederiksberg C, Denmark
}

\begin{abstract}
Micronutrient deficiencies are a major problem throughout the world and hundreds of millions of the world's population are affected by micronutrient deficiency disorders. In Europe the prevalence of clinical micronutrient deficiency disorders is less than that in the Third World. However, marginal deficiency of some of the micronutrients might be involved in the aetiology of many of the so-called lifestyle diseases, e.g. cancer, cardiovascular diseases, diabetes, osteoporosis. Supplementing domestic animals with micronutrients in excess of their needs could be one strategy to increase the intake and, thereby, status of micronutrients in the human population. This approach should, however, be considered carefully, in relation to both animal and human welfare. Many micronutrients that may accumulate in animal foods are toxic in high doses. It would also be unethical to expose animals to doses that might have deleterious effects on their health, and concentrations in animal products that might have adverse effects when consumed by man should be avoided. Furthermore, food quality should not be impaired by the supplement. On the other hand, to be relevant in relation to human nutrition, the given micronutrient should accumulate in animal tissue in concentrations that make an important contribution to total intake. Finally, the micronutrient should be incorporated in a way and in a form that is bioavailable to man, i.e. is well absorbed and utilized.
\end{abstract}

\section{Micronutrients: Animal food: Man: Micronutrient status}

\section{Prevalence of micronutrient deficiencies}

Millions of the world's population are micronutrient deficient or are at risk of becoming deficient. In Europe alone 140 million of the population are assumed to be at risk of I-deficiency disorders and approximately 100 million Europeans currently have goitres (World Health Organization, 1996). Fe deficiency and Fe-deficiency anaemia are widespread among women of childbearing age worldwide, including Europe (World Health Organization, 1996). In Denmark it has been estimated that approximately $30 \%$ of the women of childbearing age have low $\mathrm{Fe}$ stores (Milman \& Kirchhoff, 1996). Vitamin D deficiency may be a problem among the elderly who are confined to their homes and in Muslim women living in Europe (World Health Organization, 1996). Low or marginal intakes of some micronutrients might also be involved in lifestyle diseases, such as cancer, cardiovascular diseases, osteoporosis, diabetes, etc. (Richard \& Roussel, 1999). The optimal intake required to reduce the risk for these conditions is not known, but some European countries have relatively low intakes of folate, $\mathrm{Se}$ and $\mathrm{Cu}$, and it has been suggested that higher intakes might be beneficial for human health (Van Dokkum, 1995).

\section{Strategies to increase intake of micronutrients}

Changing the dietary habits of a population is difficult and may take years. An alternative or complementary approach would be to increase the concentration of nutrients in foods that are already consumed. This approach could be implemented by the use of micronutrient-enriched fertilisers for crops, by food enrichment or by supplementing domestic animals with micronutrients. Meat, milk and eggs are good sources of protein, readily-available $\mathrm{Fe}, \mathrm{Ca}, \mathrm{Mg}, \mathrm{Se}, \mathrm{Zn}$, vitamins $\mathrm{A}$ and $\mathrm{D}$ and a range of B-vitamins (Verbeke et al. 1999). In Denmark meat provides approximately $30 \%$ of the $\mathrm{Zn}, \mathrm{Cu}$, Se and niacin intake (Andersen et al. 1996), approximately $25 \%$ of the $\mathrm{Fe}$ 
and vitamin $\mathrm{B}_{6}$ intake and $>50 \%$ of the vitamin $\mathrm{B}_{12}$ intake. Milk supplies approximately $15 \%$ of the intake of retinol, vitamin $\mathrm{D}, \mathrm{Mg}, \mathrm{Zn}$, Se and some of the $\mathrm{B}$ vitamins, and $25 \%$ of the I intake. Eggs also make a small contribution to the intake of the same micronutrients as milk (Andersen et al. 1996). These levels are probably very similar in other countries where the national diet is based on animal protein. An increase in the total content of micronutrients in animal products could therefore be an effective way of improving human micronutrient status.

\section{Animal welfare and food quality}

Animal health and welfare, as well as meat quality, are important issues when considering supplementation in animals. The micronutrients most likely to be accumulated in animal tissue (e.g. Fe, $\mathrm{Zn}, \mathrm{Se}$ and vitamins $\mathrm{A}$ and D) are also the nutrients that are most toxic in high doses. Supplementing animals with doses that are toxic for them is unethical and should be discouraged. In many countries with low soil Se concentrations animals are sometimes supplemented with Se injections. However, many animals have died because of accidental administration of toxic doses resulting from errors in dilution (Shortridge et al. 1971).

Supplementation should not affect food quality, e.g. colour, oxidative stability, taste, texture etc. of meat, which determines whether a given population will buy the food and eat it. Many studies have been conducted to improve meat quality, and oxidative stability, particularly, is of great concern to the food industry. Vitamin E supplementation has been shown to improve the oxidative stability of meat from a number of different animals, including chicken, veal and pork (O'Neill et al. 1998; Corino et al. 1999; Dufrasne et al. 2000; Granit et al. 2001; Guo et al. 2001). The addition of $\mathrm{Fe}$ or $\mathrm{Cu}$, on the other hand, could have deleterious effects on meat quality, as they accelerate auto-oxidation (Snyder \& Skrydlant, 1966), the photooxidation of oxymyoglobin (Assef et al. 1971), the oxidation of reducing agents (Kanner et al. 1988) and the propagation phase in lipid peroxidation (Harel \& Kanner, 1985). Consequently, free $\mathrm{Fe}$ and $\mathrm{Cu}$ either directly or indirectly stimulate discoloration of meat, which is considered by customers to be a sign of unwholesomeness and product deterioration (Faustman \& Cassens, 1990).

\section{Efficacy of animal micronutrient supplementation}

In order to be of any benefit, the micronutrient added to animal feed should accumulate in tissues that are normally consumed by man on a regular basis. Potential candidates are the fat-soluble vitamins $\mathrm{A}, \mathrm{D}, \mathrm{E}$ and $\mathrm{K}$, some of the B-vitamins and some of the trace elements, such as Se, Fe, $\mathrm{Cu}$ and $\mathrm{Zn}$. The fat-soluble vitamins are mainly deposited in fat and liver, while trace elements are deposited both in muscle and liver, as well as in other tissues. Mattila et al. (1992) found remarkable variation in the cholecalciferol content of eggs produced by hens receiving different types of feed. Subsequently, it was shown by feeding hens different amounts of cholecalciferol $(26 \cdot 6,62 \cdot 4$ and $216.0 \mu \mathrm{g} / \mathrm{kg}$ feed) that there is a strong positive correlation between the cholecalciferol content of the feed and the cholecalciferol $(r$ 0.995) and 25-hydroxycholecalciferol ( $r$ 0.941) contents of the egg yolk (Mattila et al. 1999).

Vitamin E easily accumulates in meat (for review, see Liu et al. 1995) primarily in muscle, liver and adipose tissue (Machlin, 1994) and, in general, the greater the amount of vitamin $\mathrm{E}$ fed and/or the longer the supplementation, the higher tissue concentration of $\alpha$-tocopherol (Arnold et al. 1993). Furthermore, it has been suggested that the L- $\alpha$-tocopherol concentration of beef can be increased from $1.4 \mu \mathrm{g} / \mathrm{g}$ to the critical concentration of $3.5 \mu \mathrm{g} / \mathrm{g}$ by feeding a saturation dose of at least $1300 \mathrm{mg} / \mathrm{d}$ for $44 \mathrm{~d}$ (Arnold et al. 1993).

It is generally accepted that Se supplementation results in increased Se tissue concentrations, and many studies have shown correlations between dietary Se content and Se concentrations in animal products (for review, see Beale et al. 1990). Ruminants, however, absorb less of an oral dose than non-ruminants, probably because rumen flora are capable of converting various forms of Se into elemental Se (Pehrson et al. 1999). In single-stomached animals the absorption of Se depends on many variables, including the current Se status, the form of Se and the complexity of the diet (Levander, 1983).

Meat from Fe-supplemented animals may provide an alternative to existing methods of $\mathrm{Fe}$ fortification of food, as Fe from meat is highly available (Hurrell, 1997). Some studies have shown that increasing dietary Fe levels increases the concentration of $\mathrm{Fe}$ in muscle tissue in pigs in a dose-dependent manner (Miller et al. 1994).

The addition of $\mathrm{Cu}$ to animal feed has given conflicting results in relation to the accumulation of $\mathrm{Cu}$ in animal tissue. In studies in which pigs were fed acorns (with a high content of $\mathrm{Cu}$; Rey \& Lopez-Bote, 2001) or a $\mathrm{Cu}$ supplement (Lauridsen et al. 1999) no differences were found in muscle $\mathrm{Cu}$ concentrations. In contrast, increasing the amounts of $\mathrm{Cu}$ (from $10 \mathrm{mg} \mathrm{CuSO}_{4} / \mathrm{kg}$ to $30 \mathrm{mg} \mathrm{CuSO} 4 / \mathrm{kg}$ ) in the feed offered to ewes increased the liver $\mathrm{Cu}$ concentration of the slaughtered ewes (Eckert et al. 1999). Adding $250 \mathrm{mg} \mathrm{Cu} / \mathrm{kg}$ to feed offered to chickens increased the $\mathrm{Cu}$ concentration of breast muscle by $14 \cdot 5 \%$ (Bakalli et al. 1995). The concentrations were, however, relatively low $(<0.5 \mathrm{mg} / \mathrm{kg})$. This finding suggests that the accumulation of $\mathrm{Cu}$ in animals might depend on many factors, including animal species.

\section{Bioavailability in man}

Studies in which animal feed has been supplemented with micronutrients with the main purpose of increasing human micronutrient status are scarce. However, a number of studies have shown that many of the micronutrients present in meat are highly available, including Se (Shi \& Spallholz, 1994a,b; Wen et al. 1997), Zn (Zheng et al. 1993; Sandström, 1997) and Fe (Hurrell, 1997).

Bauch et al. (1990) have demonstrated the beneficial effect of I supplementation. Addition of I to animal feed was initiated in 1985; almost 1 year after iodized salt was introduced onto the market in Germany. During the first year, in which only iodized salt was available, urinary I excretion (a marker of I intake) increased only marginally. Introduction of I to animal feed increased urinary excretion 
markedly. During a 6-year period, the number of the population with I deficiency decreased from $>90 \%$ to approximately 30\% (Bauch et al. 1990).

Addition of vitamin $\mathrm{E}$ to pig feed has been shown to substantially increase the vitamin E content of both fat and organ meat in pigs (Morrissey et al. 1996). In one of our studies, however, the addition of vitamin $\mathrm{E}$ to pig feed only marginally increased the vitamin E content of experimental human diets containing pig products (Sandström et al. 2000).

In conclusion, supplementing animals with I might have a beneficial effect on the I status of the human population and is believed to be an effective means of eliminating most I-deficiency disorders in Europe (World Health Organization, 1996). Vitamin D supplementation of hens in order to produce enriched eggs might be a promising way of decreasing the low vitamin D status in some population groups during wintertime. The addition of Se to animal feed may be a means of improving human Se status, but its effectiveness will depend on the chemical form of Se added. The addition of $\mathrm{Fe}$ to animal feed might be beneficial to human Fe status, but only if the possible deleterious effect on meat quality can be overcome. Vitamin E supplementation of animal feed has a positive effect on meat quality but probably a very limited effect on human vitamin $\mathrm{E}$ status, as the content in the meat, even at very high levels of supplementation, is relatively low. $\mathrm{Cu}$ given in excess to animals does not appear to accumulate in animal muscle and therefore no benefits would be expected to human $\mathrm{Cu}$ status. The addition of vitamin $A$ in excess of the animal's needs is not recommended, as the risk of reaching tissue concentrations known to be toxic to man is high. The effect on human status of supplementing domestic animals with other micronutrients remains to be explored.

\section{References}

Andersen NL, Fagt S, Groth MV, Hartkopp HB, Møller A, Ovesen L \& Warming DL (1996) Danish Survey of Dietary Habits 1995. Main Results. Søborg, Denmark: National Food Agency of Denmark.

Arnold RN, Arp SC, Scheller KK, Williams SN \& Schaefer DM (1993) Tissue equilibration and subcellular distribution of vitamin E relative to myoglobin and lipid oxidation in displayed beef. Journal of Animal Science 71, 105-118.

Assef SA, Bratzler LJ, Cameron BF \& Yunis AA (1971) Photooxidation of bovine oxymyoglobin in frozen solutions. The effect of redox active inorganic elements in muscle extracts. Comparative Biochemistry and Physiology 39B, 395-407.

Bakalli RI, Pesti GM, Ragland WL \& Konjufca V (1995) Dietary copper in excess of nutritional requirement reduces plasma and breast muscle cholesterol of chickens. Poultry Science 74, 360-365.

Bauch K, Anke M, Gürtler H, Hesse V, Hiltscher A, Knappe G, Körber R, Meng W, Deckart H, Seitz W, Thomas G, Ulrich FE \& Förster ST (1990) A 5 year interdisciplinary control of iodine deficiency in the GDR. Acta Medica Austriaca 17, 36-38.

Beale AM, Fasulo DA \& Craigmill AL (1990) Effects of oral and parenteral selenium supplements on residues in meat, milk and eggs. Reviews of Environmental Contamination and Toxicology 115, 125-150.

Corino C, Oriani G, Pantaleo L, Pastorelli G \& Salvatori G (1999) Influence of dietary vitamin E supplementation on 'heavy' pig carcass characteristics, meat quality, and vitamin E status. Journal of Animal Science 77, 1755-1761.

Dufrasne I, Marche C, Clinquart A, Hornick JL, Van Eenaeme C \& Istasse L (2000) Effects of dietary vitamin E supplementation on performance and meat characteristics in fattening bulls from the Belgian Blue breed. Livestock Production Science 65, 197-201.

Eckert GE, Greene LW, Carstens GE \& Ramsey WS (1999) Copper status of ewes fed increasing amounts of copper from copper sulfate or copper proteinate. Journal of Animal Science 77, 244-249.

Faustman C \& Cassens RG (1990) Influence of aerobic metmyoglobin reducing capacity on colour stability of beef. Journal of Food Science 55, 1279-1283.

Granit R, Angel S, Akiri B, Holzer Z, Aharoni Y, Orlov A \& Kanner J (2001) Effects of vitamin E supplementation on lipid peroxidation and color retention of salted calf muscle from a diet rich in polyunsaturated fatty acids. Journal of Agricultural and Food Chemistry 49, 5951-5956.

Guo Y, Tang Q, Yuan J \& Jiang Z (2001) Effects of supplementation with vitamin $\mathrm{E}$ on the performance and the tissue peroxidation of broiler chicks and the stability of thigh meat against oxidative deterioration. Animal Feed Science and Technology 89, 165-173.

Harel S \& Kanner J (1985) Muscle membranal lipid peroxidation initiated by $\mathrm{H}_{2} \mathrm{O}_{2}$-activated metmyoglobin. Journal of Agricultural and Food Chemistry 33, 1188-1192.

Hurrell RF (1997) Bioavailability of iron. European Journal of Clinical Nutrition 51, S4-S8.

Kanner J, Hazan B \& Doll L (1988) Catalytic free iron in muscle food. Journal of Agricultural and Food Chemistry 36, 412-415.

Lauridsen C, Holm Nielsen J, Henckel P \& Tang Sorensen M (1999) Antioxidative and oxidative status in muscles of pigs fed on rapeseed oil, vitamin E, and copper. Journal of Animal Science 77, 105-115.

Levander OA (1983) Considerations in the design of selenium bioavailability studies. Federation Proceedings 42, 1721-1725.

Liu Q, Lanari MC \& Schaefer DM (1995) A review of dietary vitamin E supplementation for improvement of beef quality. Journal of Animal Science 73, 3131-3140.

Machlin LJ (1994) New views on the function and health effects of vitamins (editorial). Nutrition 10, 562.

Mattila P, Lehikoinen K, Kiiskinen T \& Piironen V (1999) Cholecalciferol and 25-hydroxycholecalciferol content of chicken egg yolk as affected by the cholecalciferol content of feed. Journal of Agricultural and Food Chemistry 47, 4089-4092.

Mattila P, Piironen V, Bäckman C, Asunmaa A, Uusi-Rauva E \& Koivistoinen P (1992) Determination of vitamin D3 in egg yolk by high performance liquid chromatography (HPLC) with diode array detection. Journal of Food Composition Analysis $\mathbf{5}$, 281-290.

Miller DK, Gomez-Basauri JV, Smith VL, Kanner J \& Miller DD (1994) Dietary iron in swine rations affects nonheme iron and TBARS in pork skeletal muscle. Journal of Food Science $\mathbf{5 9}$ 747-750.

Milman N \& Kirchhoff M (1996) Relationship between serum ferritin, alcohol intake, and social status in 2235 Danish men and women. Annals of Hematology 72, 145-151.

Morrissey PA, Buckley DJ, Sisk H, Lynch PB \& Sheehy PJA (1996) Uptake of alpha-tocopherol in porcine plasma and tissues. Meat Science 44, 275-283.

O’Neill LM, Galvin K, Morrissey PA \& Buckley DJ (1998) Comparison of effects of dietary olive oil, tallow and vitamin $\mathrm{E}$ on the quality of broiler meat and meat products. British Poultry Science 39, 365-371.

Pehrson B, Ortman K, Madjid N \& Trafikowska U (1999) The influence of dietary selenium as selenium yeast or sodium selenite on the concentration of selenium in the milk of suckler 
cows and on the selenium status of their calves. Journal of Animal Science 77, 3371-3376.

Rey AI \& Lopez-Bote CJ (2001) Effect of dietary copper and vitamin E supplementation, and extensive feeding with acorn and grass on longissimus muscle composition and susceptibility to oxidation in Iberian pigs. Journal of Animal Physiology and Animal Nutrition 85, 281-292.

Richard MJ \& Roussel AM (1999) Micronutrients and ageing: intakes and requirements. Proceedings of the Nutrition Society 58, 573-578.

Sandström B (1997) Bioavailability of zinc. European Journal of Clinical Nutrition 51, S17-S19.

Sandström B, Bügel S, Lauridsen C, Nielsen F, Jensen C \& Skibsted LH (2000) Cholesterol-lowering potential in human subjects of fat from pigs fed rapeseed oil. British Journal of Nutrition 84, 143-150.

Shi B \& Spallholz JE (1994a) Bioavailability of selenium from raw and cooked ground beef assessed in selenium-deficient Fischer rats. Journal of the American College of Nutrition 13, 95-101.

Shi B \& Spallholz JE (1994b) Selenium from beef is highly bioavailable as assessed by liver glutathione peroxidase (EC 1.11.1.9) activity and tissue selenium. British Journal of Nutrition 72, 873-881.
Shortridge EH, O’Hara PJ \& Marshall PM (1971) Acute selenium poisoning in cattle. New Zealand Veterinary Journal 19, 47-50.

Snyder HE \& Skrydlant HB (1966) The influence of metallic ions on the autoxidation of oxymyoglobin. Journal of Food Science 31, 468-479.

Van Dokkum W (1995) The intake of selected minerals and trace elements in European countries. Nutrition Research Reviews 8, 271-302.

Verbeke W, Van Oeckel MJ, Warnants N, Viaene J \& Boucqué ChV (1999) Consumer perception, facts and possibilities to improve acceptability of health and sensory characteristics of pork. Meat Science 53, 77-99.

Wen HY, Davis RL, Shi B, Chen JJ, Chen L, Boylan M \& Spallholz JE (1997) Bioavailability of selenium from veal, chicken, beef, pork, lamb, flounder, tuna, selenomethionine, and sodium selenite assessed in selenium-deficient rats. Biological Trace Element Research 58, 43-53.

World Health Organization (1996) Trace Elements in Human Nutrition and Health. Geneva: WHO.

Zheng JJ, Mason JB, Rosenberg IH \& Wood RJ (1993) Measurement of zinc bioavailability from beef and a ready-to-eat high fiber breakfast cereal in humans: application of a whole-gut lavage technique. American Journal of Clinical Nutrition 58, 902-907. 